\title{
Analisis Ketahanan Hidup Lima Tahun Kanker Tiroid yang Dikelola di RSUP Dr. M. Djamil Padang
}

\author{
Oktahermoniza ${ }^{1}$, Wirsma Arif Harahap ${ }^{2}$, Tofrizal $^{3}$, Rosfita Rasyid $^{4}$
}

\begin{abstract}
Abstrak
Kanker tiroid merupakan kanker yang jarang terjadi, namun kanker tersering pada organ endokrin. Tujuan penelitian ini untuk mengetahui ketahanan hidup lima tahun kanker tiroid yang di tatalaksana di RS Dr. M. Djamil Padang dari Januari 2007 sampai dengan Desember 2011. Metode: Subjek penelitian adalah 117 penderita kanker tiroid yang ditatalaksana di RS Dr. M. Djamil Padang dari Januari 2007 sampai dengan Desember 2011. Data dianalisis dengan pendekatan survival time menggunakan Kaplan-Meier survival curve dan Log rank test. Hasil: Median umur 39 tahun (range, 11 sampai 77 tahun), median waktu follow up 32 bulan (range, 1 sampai 70 bulan), median ukuran tumor $6 \mathrm{~cm}$ (range, 1 sampai $16 \mathrm{~cm}$ ). Didapatkan $100(85,5 \%) \%)$ penderita sehat bebas tumor, $7(6 \%)$ penderita kambuh lokal, $1(0,9 \%)$ metastasis jauh serta $9(7,7 \%)$ penderita meninggal. Overall five survival rate pada penelitian ini 92,3\%. Faktor umur, ukuran tumor, dan jenis histopatologi berhubungan secara bermakna dengan survival $(p 0,000),(p=0,046)$ dan $(p=0,000)$. Sedangkan faktor-faktor jenis kelamin, jenis operasi, dan terapi adjuvan tidak mempunyai hubungan bermakna dengan survival. Pembahasan: Umur, ukuran tumor, dan jenis histopatologi memiliki hubungan bermakna dengan survival. Jenis kelamin, jenis operasi, dan terapi adjuvan tidak tidak berhubungan bermakna dengan survival.
\end{abstract}

Kata kunci: Umur, Ukuran Tumor, Jenis Histopatologi, Survival, Kanker Tiroid

\begin{abstract}
Thyroid cancer is a rare cancer, but most common in endocrine organ. The purpose of this research is to determine about at five year survival of thyroid cancer which recorded at RS M. Djamil Padang Hospital from January 2007 until December 2011. Methods: Subjects were 117 patients with thyroid cancer be recorded in hospital Dr. M. Djamil Padang from January 2007 to December 2011. Data were analyzed with the survival time using Kaplan-Meier survival curve and log rank test. Result: Median age 39 years (range, 11 to 77 years), median follow-up time of 32 months (range, 1 to 70 months), median tumor size was $6 \mathrm{~cm}$ (range, 1 to $16 \mathrm{~cm}$ ). Obtained 100 (85.5\%)\%) patients with tumor-free healthy, 7 (6\%) patients with local recurrence, 1 (0.9\%) distant metastases, and 9 (7.7\%) patients died. Five overall survival rate in this study was $92.3 \%$. Factors of age, tumor size and histopathological type was significantly associated with survival ( $p 0.000),(p=0.046)$ and $(p=0.000)$. While the factors gender, type of surgery, and adjuvant therapy had no significant association with survival. Discussion: Discussion: Age, tumor size and histopathological type has a significant relationship with survival. Gender, type of surgery, and adjuvant therapy did not significantly associated with survival.
\end{abstract}

Keywords: Age, Tumor Size, Type of Histopathology, Survival, Thyroid Cancer

Affiliasi penulis : Oktahermoniza,

Korespondensi : 1. Bagian Bedah Fak Kedokteran Unand, email : oktahermoniza@hotmail.co.uk,Telp/Hp : 081365300100

\section{Pendahuluan}

Kanker tiroid merupakan keganasan endokrin yang tersering dijumpai dan diperkirakan 1,1\% dari seluruh keganasan manusia. Pada tahun 2004 American Cancer Society memperkirakan terdapat lebih kurang 22.500 kasus baru kanker tiroid di Amerika Serikat. Dimana perbandingan perempuan dan laki-laki adalah 3 : 1, dengan estimasi 16.875 kasus pada perempuan dan 5.625 kasus pada lakilaki. ${ }^{1}$ Di Indonesia dari registrasi Perhimpunan Dokter Spesialis Patologi Indonesia didapatkan kanker tiroid menempati urutan ke 9 dari 10 kanker terbanyak $(4,43 \%)^{2}$

Kanker tiroid umumnya tergolong tumor dengan pertumbuhan dan perjalanan penyakit yang lambat, serta morbiditas dan mortalitas yang rendah, terutama pada kanker tiroid tipe papiler. ${ }^{3}$ Mortalitas paling rendah pada individu dengan usia dibawah 50 tahun dan meningkat tajam pada usia di atasnya, namun sebagian kecil ada pula yang tumbuh cepat dan sangat ganas dengan prognosis yang fatal. ${ }^{4}$ Angka rekurensi tumor umum pada kanker tiroid tipe papiler, berkisar setinggi $30 \%$ jika terapi awal tidak komplit. ${ }^{3}$ Angka kematian akibat kanker tiroid 0,4\% dari semua kematian akibat kanker atau berkisar 5 kematian per sejuta penduduk pertahun. Angka ketahanan hidup lima tahun relatif kanker tiroid adalah $96 \% .^{5}$ Tujuan utama tata laksana kanker tiroid adalah memperkecil resiko rekurensi dan metastasis jauh, sehingga bisa menurunkan angka morbiditas dan mortalitas penderita. Terapi utama dalam tata laksana kanker tiroid adalah operasi, sedangkan terapi adjuvan adalah ablasi tiroid dengan iodine radioaktif, supresi thyrotropin dan radiasi eksternal. ${ }^{6}$

Beberapa faktor prognostik telah diteliti dan ditemukan pada kanker tiroid. Faktor penderita dan faktor tumor yang meliputi umur, jenis kelamin, ukuran tumor, jenis dan grading histopatologi, invasi lokal, multicentriciti dan adanya metastasis merupakan prediktor independen pada prognosis. 
Penelitian ini ditujukan untuk memperoleh informasi tentang faktor-faktor yang mempengaruhi ketahanan hidup lima tahun kanker tiroid di RS. Dr. M Djamil, Padang. Selain itu diketahuinya besarnya angka harapan hidup lima tahun kanker tiroid di tata laksana di RS Dr. M. Djamil Padang.

\section{METODE}

Penelitian ini merupakan penelitian retrospektif dengan mengumpulkan data tentang keadaan penderita kanker tiroid yang pernah dirawat dibagian bedah RS Dr. M. Djamil Padang dari tanggal 1 Januari 2007 sampai dengan 31 Desember 2011.

Data diolah dengan program komputer kemudian dilakukan analisa kesintasan metode Kaplan-Meier product-limit. Log-rank test digunakan untuk mendapatkan perbedaan antara subvariabel. Kemaknaan ditentukan dengan nilai $p<0,05$.

\section{HASIL}

\section{Karakteristik Penderita Kanker Tiroid}

Dari data rekam medis kurun waktu 2007 sampa 2011 didapatkan 210 penderita kanker tiroid yang mendapat pengobatan dan didiagnosa di RSUP Dr. M. Djamil Padang. Jumlah penderita yang memenuhi kriteria inklusi pada penelitian ini adalah sebanyak 117. Median umur 39 tahun (range, 11 sampai 77 tahun). Median waktu follow up 32 bulan (range, 1 sampai 70 bulan). Didapatkan 100 (85,5\%) penderita sehat bebas tumor $7(6 \%)$ penderita kambuh lokal, 1 $(0,9 \%)$ metastasis jauh serta $9(7,7 \%)$ penderita meninggal.

Jenis kelamin penderita yang diteliti terdiri atas 16 (13,7\%) penderita laki-laki dan 101 (86,3\%) penderita perempuan, usia terbanyak adalah pada dekade ketiga yaitu sebanyak $32(27,4 \%)$ penderita. Berdasarkan ukuran tumor didapatkan median ukuran tumor $6 \mathrm{~cm}$ (range, 1 sampai $16 \mathrm{~cm}$ ). Sebanyak $57,3 \%$ ukuran tumor diatas $5 \mathrm{~cm}$. Berdasarkan jenis histopatologik yang terbanyak adalah jenis papiler yaitu sebanyak $52,1 \%$. Berdasarkan jenis operasi yang dilakukan sebanyak 74 penderita atau 63,2\% dilakukan hemi tiroidektomi. Radioablasi dilakukan pada 20 penderita $(17,1 \%)$, sedangkan terapi supresi dijalani oleh 21 penderita $(17,9)$. Selengkapnya karakteristik penderita kanker tiroid dapat dilihat pada tabel 1.

Tabel 1. Karakteristik penderita kanker tiroid di RSUP Dr. M. Djamil tahun 2007-2011

\begin{tabular}{clcc} 
& $\begin{array}{l}\text { Hemi } \\
\text { tiroidektomi }\end{array}$ & 74 & 63,2 \\
& Total \\
tiroidektomi & & 36,8 \\
Terapi adjuvan & & \\
& Supresi & & \\
Outcome & Radioablasi & 21 & 17,9 \\
& & & 17,1 \\
& Bebas & 100 & \\
& tumor & 7 & 65,5 \\
& Kambuh & 1 & 0.9 \\
& lokal & 9 & 7,7 \\
& Metastase & $\mathbf{1 1 7}$ & $\mathbf{1 0 0}$ \\
Total & Meninggal & & \\
\hline
\end{tabular}

2. Overall Survival Penderita Kanker Tiroid menurut Kaplan-Meier

Survival Function

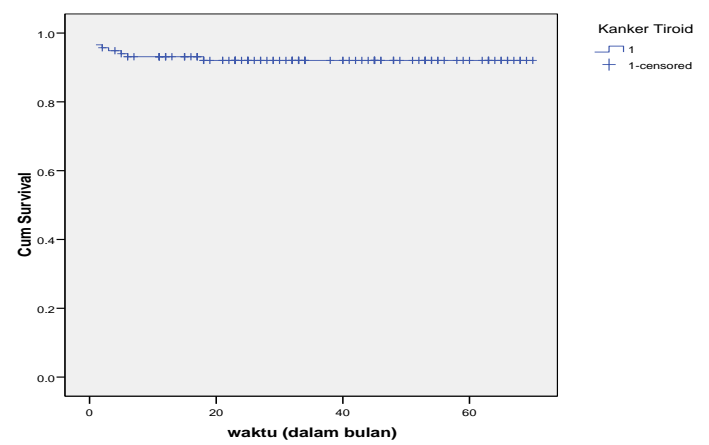

Gambar 1. Kesintasan kumulatif kanker tiroid

Analisa kesintasan kumulatif kanker tiroid tampak pada gambar 1. Didapatkan overall five survival rate kanker tiroid adalah 92,3\%.

3. Faktor Yang Berhubungan Survival a. Berdasarkan Distribusi Umur Penderita

Tabel 2. Karakteristik ukuran tumor penderita kanker tiroid dan hubungannya dengan survival di RSUP dr. M. Djamil tahun 2007-2011

\begin{tabular}{|c|c|c|c|c|}
\hline Karakteristik & $\begin{array}{l}\text { Hidup } \\
\text { n(\%) }\end{array}$ & $\begin{array}{c}\text { Meningg } \\
\text { al } \\
\text { n (\%) } \\
\end{array}$ & $\begin{array}{c}\text { Jumlah } \\
\text { n (\%) }\end{array}$ & Nilai $p$ \\
\hline $\begin{array}{l}<45 \\
\geq 45\end{array}$ & $\begin{array}{c}75 \\
(98,7) \\
33 \\
(80,5) \\
\end{array}$ & $\begin{array}{c}1(1,3) \\
8(19,5)\end{array}$ & $\begin{array}{l}76(65) \\
41(35)\end{array}$ & \multirow[t]{2}{*}{0,000} \\
\hline & & & $117(100)$ & \\
\hline
\end{tabular}

\begin{tabular}{|c|c|c|}
\hline Karakteristik & $\begin{array}{l}\text { Jumlah } \\
\text { Penderita }\end{array}$ & Persen \\
\hline \multicolumn{3}{|l|}{ Umur } \\
\hline$\leq 20$ & 11 & 9,4 \\
\hline $21-30$ & 20 & 17,2 \\
\hline $31-40$ & 32 & 27,4 \\
\hline $41-50$ & 24 & 20,5 \\
\hline $51-60$ & 16 & 13,7 \\
\hline $61-70$ & 8 & 6,8 \\
\hline$>70$ & 6 & 5,1 \\
\hline \multicolumn{3}{|l|}{ Jenis kelamin } \\
\hline Laki-laki & 16 & 13.7 \\
\hline Perempuan & 101 & 86.3 \\
\hline \multicolumn{3}{|l|}{ Ukuran tumor } \\
\hline$\leq 5 \mathrm{~cm}$ & 50 & 42,7 \\
\hline$>5 \mathrm{~cm}$ & 67 & 57,3 \\
\hline \multicolumn{3}{|l|}{ Jenis histopatologi } \\
\hline Papiler & 61 & 52,1 \\
\hline Folikuler & 49 & 41,8 \\
\hline Medulare & 2 & 1,7 \\
\hline Anaplastik & 5 & 4,3 \\
\hline
\end{tabular}




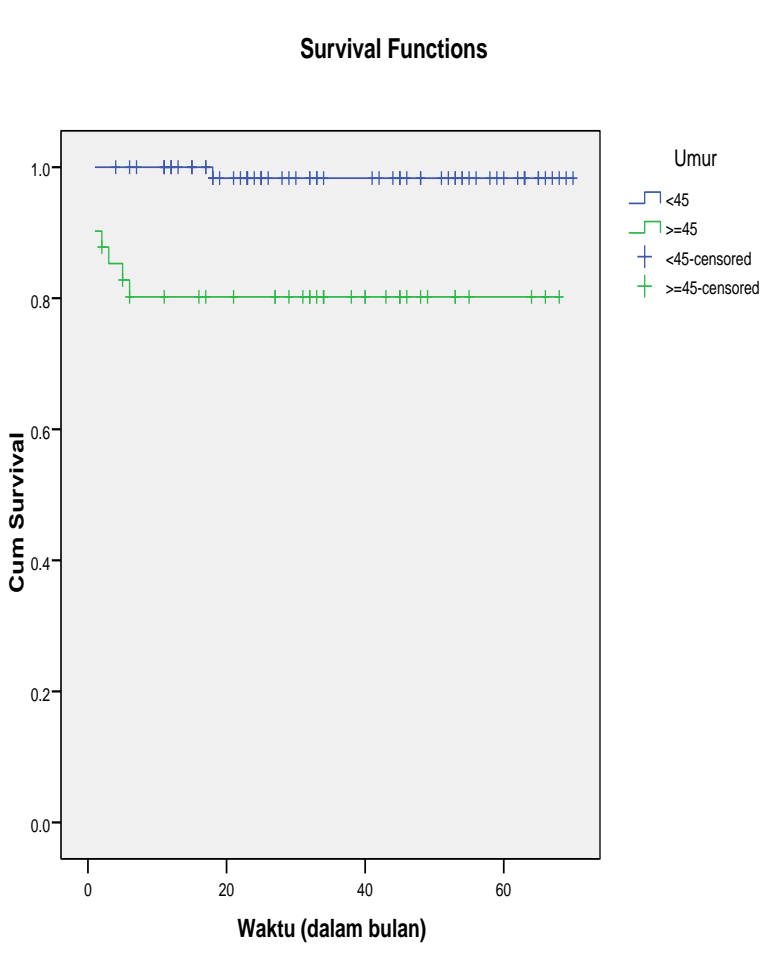

\section{Gambar 2. Kesintasan berdasar umur}

Berdasarkan metode Kaplen-Meier, ternyata umur dibawah 45 tahun survivalnya lebih baik, survival 5 tahun 98,7\%; lebih baik dari umur 45 tahun keatas, survival 5 tahun 80,5\%. Pada uji statistik perbedaan ini bermakna $(p=0,000)(G b .2)$.

\section{b. Berdasarkan Distribusi Jenis Kelamin Penderita}

Tabel 3. Karakteristik jenis kelamin penderita kanker tiroid dan hubungannya dengan survival di RSUP dr. M. Djamil tahun 2007-2011

\begin{tabular}{ccccc}
\hline Karakteristik & $\begin{array}{c}\text { Hidup } \\
\mathbf{n}(\%)\end{array}$ & $\begin{array}{c}\text { Menin } \\
\text { ggal } \\
\mathbf{n}(\%)\end{array}$ & $\begin{array}{c}\text { Jumlah } \\
\mathbf{n}(\%)\end{array}$ & Nilai $\mathbf{p}$ \\
\hline \hline Jenis kelamin & & & & \\
Laki- & & 3 & 16 & \\
laki & 13 & $(18,8)$ & $(13,7)$ & 0,063 \\
Perem & $(81,3)$ & $6(5,9)$ & 101 & \\
puan & 95 & & $(86,3)$ & \\
& $(94,1)$ & & 117 & \\
Total & & & $(100)$ & \\
\end{tabular}

Survival Functions

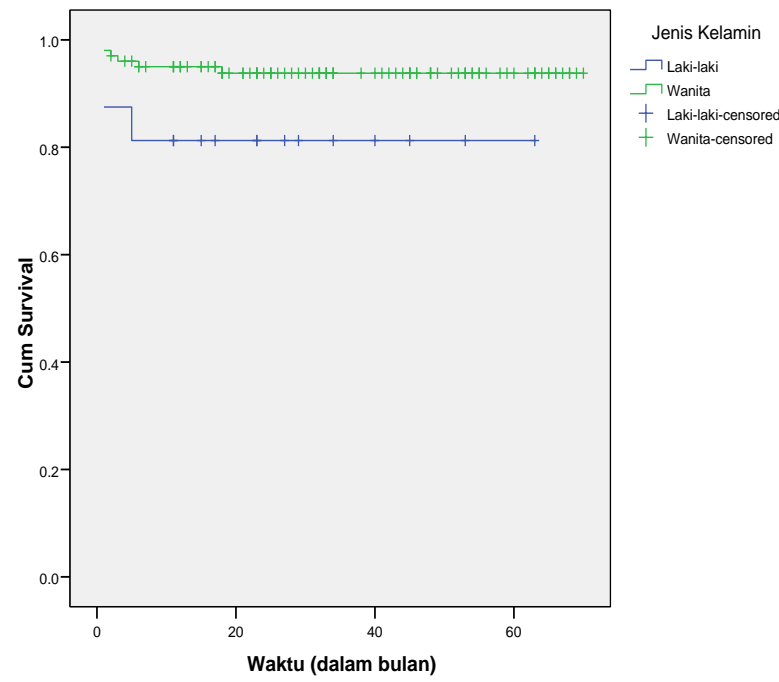

Gambar 3. Kesintasan berdasar jenis kelamin

Perempuan lebih baik survivalnya daripada lakilaki. Survival 5 tahun perempuan $94,1 \%$ dibanding laki-laki $81,3 \%$. Akan tetapi perbedaan tersebut secara statistik tidak bermakna ( $p=0.063)$ (Gb.3).

\section{c. Berdasarkan Distribusi Ukuran Tumor Penderita}

Tabel 4. Karakteristik ukuran tumor penderita kanker tiroid dan hubungannya dengan survival di RSUP dr. M. Djamil tahun 2007-2011

\begin{tabular}{|c|c|c|c|c|}
\hline Karakteristik & $\begin{array}{l}\text { Hidup } \\
\text { n (\%) }\end{array}$ & $\begin{array}{c}\text { Mening } \\
\text { gal } \\
n(\%)\end{array}$ & $\begin{array}{c}\text { Jumlah } \\
\mathrm{n}(\%)\end{array}$ & Nilai $p$ \\
\hline \multirow[t]{3}{*}{ Ukuran } & & & & 0,046 \\
\hline & $49(98)$ & $1(2)$ & $\begin{array}{c}50 \\
(42,7)\end{array}$ & \\
\hline & $\begin{array}{c}59 \\
(88,1)\end{array}$ & $8(11,9)$ & $\begin{array}{c}67 \\
(57,3)\end{array}$ & \\
\hline Total & & & $\begin{array}{c}117 \\
(100)\end{array}$ & \\
\hline
\end{tabular}

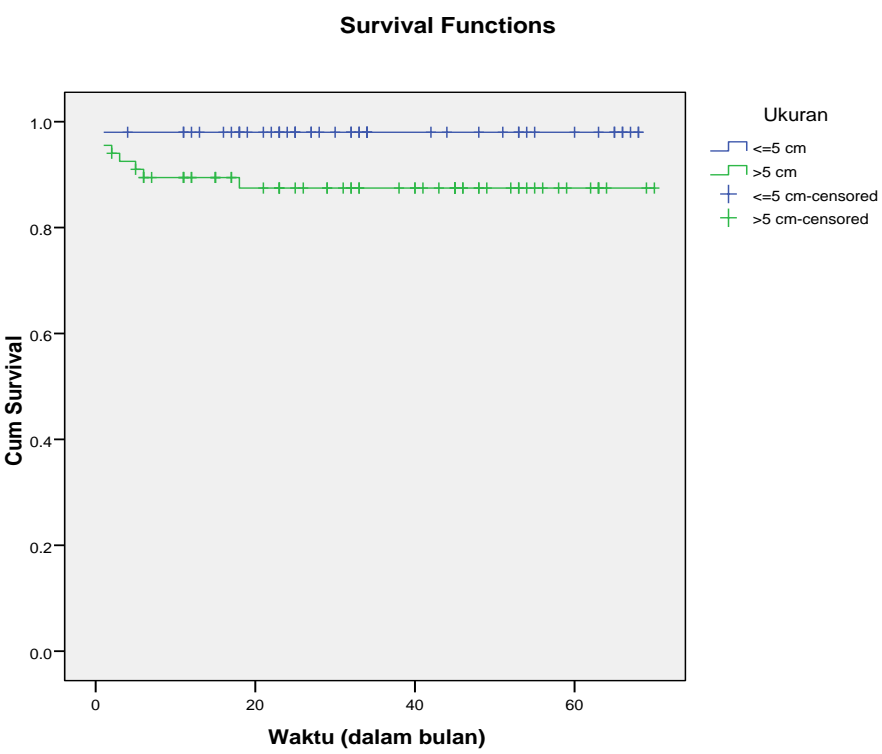

Gambar 4. Kesintasan berdasar ukuran tumor 
Survival 5 tahun ukuran tumor $\leq 5 \mathrm{~cm}$ adalah $98 \%$ - sangat baik, sedangkan ukuran tumor $>5 \mathrm{~cm}$ survival 5 tahun adalah $88,1 \%$. Perbedaan ini secara statistik bermakna $(p=0,046)(G b .4)$.

d. Berdasarkan Distribusi Jenis histopatologi Penderita

Tabel 5. Karakteristik jenis histopatologi penderita kanker tiroid dan hubungannya dengan survival di RSUP dr. M. Djamil tahun 2007-2011

\begin{tabular}{ccccc}
\hline Karakteristik & $\begin{array}{c}\text { Hidup } \\
\mathbf{n}(\%)\end{array}$ & $\begin{array}{c}\text { Meningga } \\
\mathbf{I} \\
\mathbf{n}(\%)\end{array}$ & $\begin{array}{c}\text { Jumlah } \\
\mathbf{n}(\%)\end{array}$ & Nilai p \\
\hline Jenis Histopatologi & & & & 0,000 \\
Papiler & $60(98,4)$ & $1(1,6)$ & 61 & $(52,1)$ \\
Folikuler & $47(95,9)$ & $2(4,1)$ & $\begin{array}{c}49 \\
(41,8)\end{array}$ & \\
Medulare & $1(50)$ & $1(50)$ & $2(1,7)$ & \\
Anaplastik & $0(0)$ & $5(100)$ & $5(4,3)$ & \\
& & & 117 & \\
\hline & Total & & $(100)$ & \\
\hline
\end{tabular}

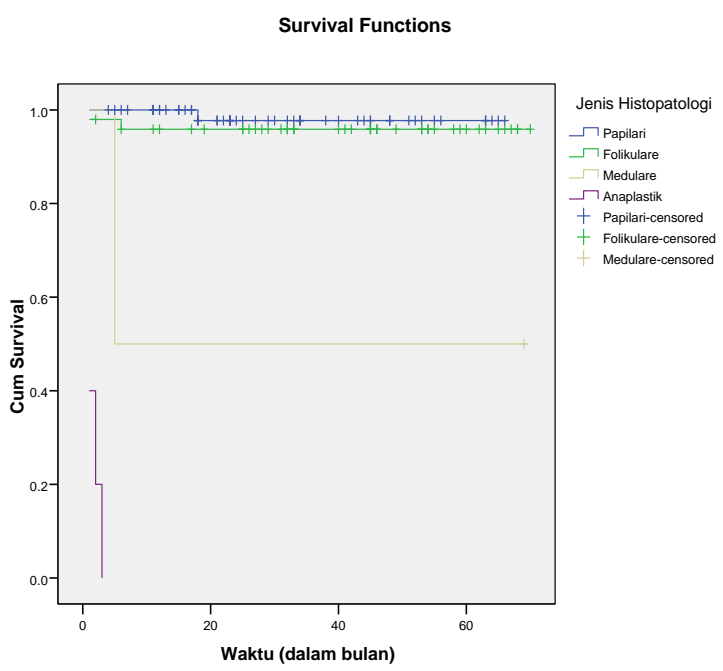

\section{Gambar 5. Kesintasan berdasar jenis histopatologi}

Survival 5 tahun tipe papiler $98,4 \%$ - sangat baik folikuler sebesar 95,9\%, medulare hanya $50 \%$, Anaplastik suvivalnya hanya 3 bulan. Perbedaan ini secara statistik sangat bermakna $(p=0,000)(G b .5)$.

\section{e. Berdasarkan Distribusi Jenis Operasi Penderita}

Tabel 6. Karakteristik jenis operasi dan hubungannya dengan survival di RSUP dr. M. Djamil tahun 2007-2011

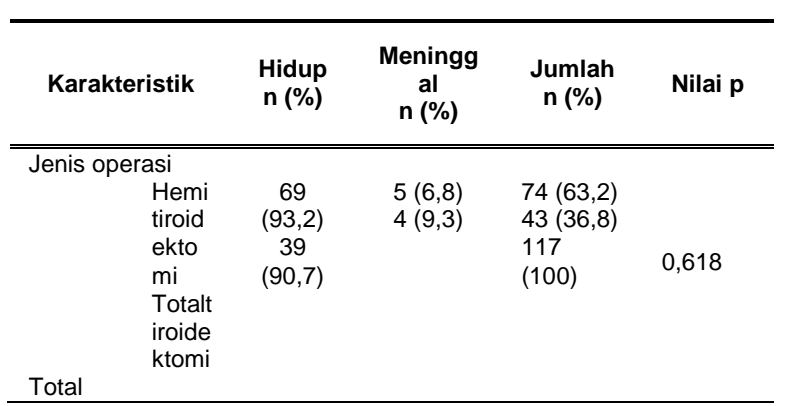

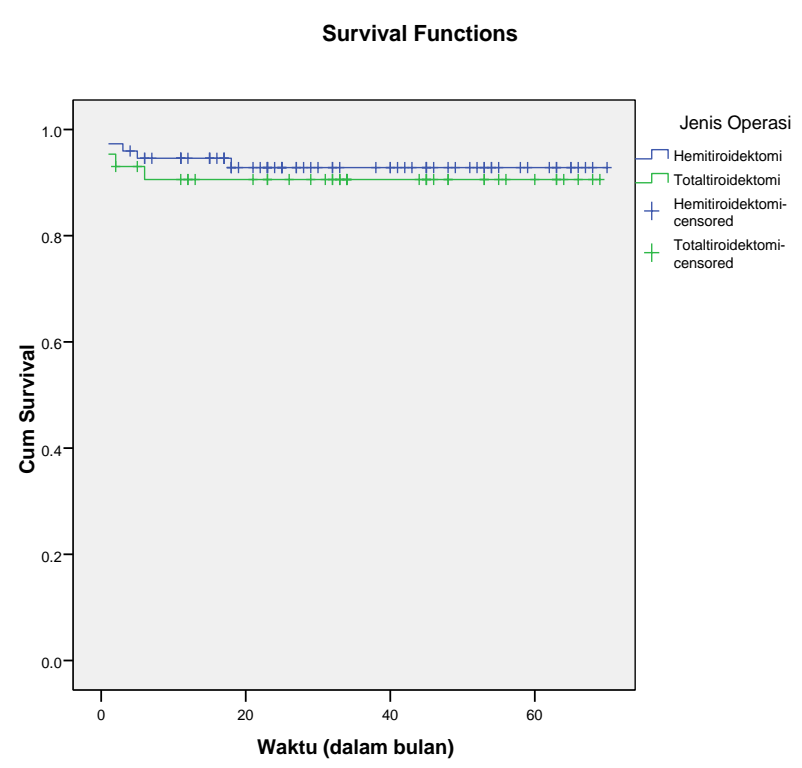

Gambar 6. Kesintasan berdasar jenis operasi

Survival 5 tahun jenis operasi hemitiroid adalah $93,2 \%$, lebih baik dibanding jenis operasi total tiroidektomi 90,7\%. Namun perbedaan ini secara statistik tidak bermakna $(p=0,618)(G b .6)$.

\section{f. Berdasarkan Terapi Adjuvan}

Tabel 7. Karakteristik terapi adjuvan dan hubungannya dengan survival di RSUP dr. M. Djamil tahun 2007-2011

\begin{tabular}{lcccc}
\hline Karakteristik & $\begin{array}{c}\text { Hidup } \\
\mathbf{n}(\%)\end{array}$ & $\begin{array}{c}\text { Mening } \\
\text { gal } \\
\mathbf{n}(\%)\end{array}$ & $\begin{array}{c}\text { Jumlah } \\
\mathbf{n}(\%)\end{array}$ & Nilai p \\
\hline Terapi adjuvan & & & & 0,506 \\
*Tidak terapi adjuvan & 89 & $7(7.3)$ & 96 & \\
& $(92.7)$ & & $(82,1)$ & \\
*Mendapat terapi & 19 & 21 & \\
adjuvan & $(90,5)$ & $2(9,5)$ & $(17,9)$ & \\
\hline Total & & & 117 \\
& & & $(100)$ & \\
\hline
\end{tabular}

Survival Functions

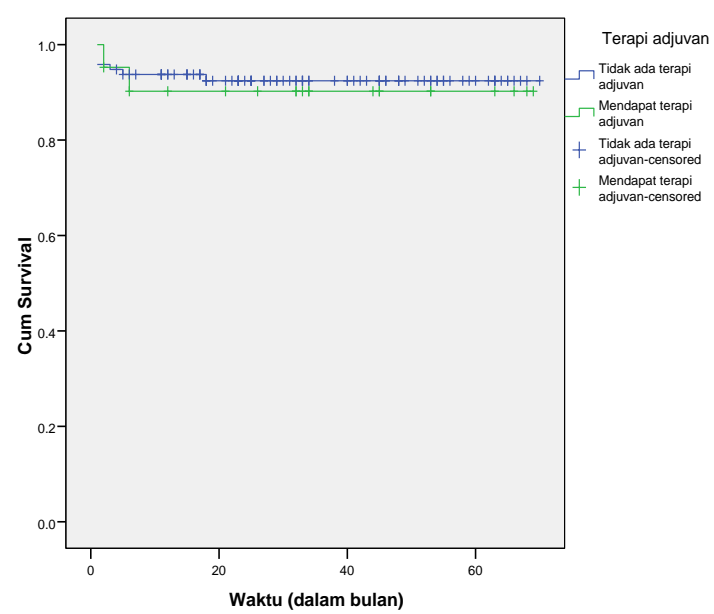

Gambar 7. Kesintasan berdasar terapi adjuvan 
Survival 5 tahun mendapat terapi adjuvan adalah $90,5 \%$, lebih rendah dibanding dengan yang tidak mendapat terapi adjuvan 92,7\%. Akan tetapi perbedaan ini secara statistik tidak bermakna $(p=0,506)(G b .7)$

\section{PEMBAHASAN}

Jumlah penderita yang memenuhi kriteria inklusi pada penelitian ini adalah sebanyak 117 orang dari total 210 penderita yang didiagnosa di RSUP Dr. M. Djamil Padang periode Januari 2007 hingga Desember 2011. Kesulitan mendapatkan alamat penderita oleh karena tidak ditemukannya rekam medik penderita. Hal ini mungkin hilang karena bencana gempa tahun 2009 yang menimpa kota Padang. Gedung rekam medik RS Dr. M. Djamil Padang ikut runtuh. Kesulitan lain adalah tidak lengkapnya identitas penderita yang tercantum di dalam rekam medik rumah sakit.

Analisis deskripsi terhadap umur didapatkan usia termuda adalah perempuan 11 tahun, penderita ini dilakukan total tiroidektomi, dan tipe histopatologinya adalah papiler. Usia paling tua adalah perempuan 77 tahun, penderita ini dilakukan hemitiroidektomi dan jenis histopatologinya adalah folikuler. Saat ditemukan oleh peneliti penderita ini masih hidup dengan tumor kambuh lokal di bekas operasi di leher penderita. Insiden kanker tiroid pada penelitian ini terbanyak didapatkan pada dekade ketiga yaitu 32 penderita atau 27,4\%. Hasil penelitian ini sama dengan penelitian Blake Cady dengan insiden tertinggi pada dekade ketiga yaitu 26\%. ${ }^{8}$ Hal ini berbeda dengan yang dilaporkan oleh Dian Asih Lestari di RSCM Jakarta yaitu insiden terbanyak adalah pada dekade keempat, ${ }^{9}$ dan dari data Surveillance, Epidemiology, and End Results (SEER) juga mendapatkan dekade keempat adalah yang terbanyak. ${ }^{3}$

Penderita umur 45 tahun atau lebih mempunyai resiko mortalitas lebih tinggi dibandingkan umur 45 tahun kebawah $(p=0,000)$ (gb.2). Hal ini mungkin disebabkan oleh karena kanker tiroid diferensiasi baik banyak diderita oleh umur muda, sedangkan tidak berdiferensiasi (anaplastik) banyak diderita oleh usia 60 tahun keatas. Hasil ini sama dengan yang didapatkan oleh $\mathrm{R}$. Sciuto dan kawankawan survival umur 45 tahun kebawah lebih tinggi secara bermakna dibandingkan dengan umur diatas 45 tahun, $^{10}$ demikian juga dengan yang didapatkan oleh Brandon M. Barney yang menggunakan data base dari Surveillance, Epidemiology, and End Results (SEER) pada 23, 605 penderita kanker tiroid dari tahun 1983 sampai 2002 yang mendapatkan umur 45 tahun kebawah survivalnya lebih tinggi secara bermakna dibandingkan umur diatas 45 tahun. ${ }^{11}$

Jenis kelamin penderita sebagian besar adalah perempuan yaitu sebanyak 101 (86,3\%) dengan perbandingan perempuan dan laki-laki 7:1. Di Indonesia perbandingan penderita perempuan dan laki-laki lebih tinggi dibandingkan dengan luar negeri dimana perbandingan perempuan:laki-laki sebesar $2: 1$ hingga $3: 1{ }^{5}$

Analisis statistik dengan menggunakan kurva Kaplan-Meier dan Log rank untuk jenis kelamin (gb.3), didapatkan perempuan mempunyai survival 5 tahun yang lebih baik $(94,1 \%)$ dibandingkan laki-laki $(81,3 \%)$. Tetapi secara statistik perbedaan ini tidak bermakna $(p=0,063)$. Hasil ini sama dengan yang didapatkan oleh Maria Luisa Carcangiu yang mengadakan penelitian pada 240 kasus di Bagian Patologi Anatomi Fakultas Kedokteran Florensia Universitas Florensia Italia, ${ }^{12}$ D.J. Kerr pada penelitian 495 penderita kanker tiroid dari tahun 1957 sampai 1982 di Departemen Medikal Onkologi, Radioterapi dan Patologi Universitas Glasgow, ${ }^{13}$ dan Hemen K. Parikh dengan 417 penderita kanker tiroid yang diobati dari tahun 1971 sampai 1985 di RS Tata Memorial Bombay India, ${ }^{14}$ juga tidak mendapatkan perbedaan survival yang bermakna antara jenis kelamin laki-laki dan perempuan.

Hasil yang berbeda didapatkan oleh $\mathrm{R}$. Sciuto, pada penelitian retrospektif pada 1.503 penderita kanker tiroid berdeferensiasi di Divisi Kedokteran Nuklir Institut Kanker Nasional 'Regina Elena' Roma Italia tahun 1991-2006, mendapatkan perbedaan survival yang bermakna antara jenis kelamin laki-laki dan perempuan. ${ }^{(10)}$

Pada variabel ukuran tumor pada penelitian ini didapatkan survival 5 tahun ukuran tumor $\leq 5 \mathrm{~cm}$ (98\%) lebih tinggi secara bermakna dibandingkan dengan ukuran tumor $>5 \mathrm{~cm} \quad(88,1 \%) \quad(p=0,046)$ (gb.4). Hal ini sama dengan penelitian-penelitian lain seperti yang didapatkan oleh D. J Kerr bahwa ukuran tumor berhubungan secara bermakna dengan survival. ${ }^{(13)}$ Demikian juga dengan Hemen K Parikh dan kawan-kawan, mendapatkan ukuran tumor $5 \mathrm{~cm}$ kebawah survivalnya lebih tinggi secara bermakna dibandingkan dengan ukuran tumor diatas $5 \mathrm{~cm} .{ }^{(14)}$

Gambaran histopatologi terbanyak pada penelitian ini adalah tipe papiler yaitu 61 penderita $(52,1 \%)$ diikuti tipe folikuler 49 penderita $(41,8 \%)$ (kanker tiroid berdiferensiasi baik 110 atau 94\% dari total sampel), tipe anaplastik 5 penderita $(4,3 \%)$ dan yang paling sedikit yaitu tipe medulare 2 penderita $(1,7 \%)$. Data dari kepustakaan juga menyebutkan bahwa yang terbanyak adalah tipe papiler $70-80 \%$ diikuti oleh tipe folikuler $10-20 \%$, kemudian tipe medulare dan tipe anaplastik masing-masing 2-6\% dan $5-10 \%$. ${ }^{(15)}$ Dalam penelitian ini didapatkan persentase kanker tiroid tipe folikuler $(41,8 \%)$ lebih tinggi dibandingkan dengan data dari kepustakaan yang berkisar antara $10-20 \%$. Hal ini mungkin disebabkan oleh karena tingginya prevalensi endemik goiter di daerah Sumatera Barat.

Analisa statistik mendapatkan bahwa tipe histopatologi berhubungan secara bermakna dengan survival $(p=0,000)$ (gb.5). Ketahanan hidup 5 tahun terbaik terdapat pada tipe papiler $(98,4 \%)$, sedangkan tipe folikuler dan meduler masing-masing 95,9\% dan $50 \%$. Ketahanan hidup kanker tiroid tipe anaplastik pada penelitian ini hanya 3 bulan. Hasil penelitian ini sesuai dengan yang didapatkan oleh Kaarle $O$ Franssila pada penelitian terhadap 227 kasus kanker tiroid yang mengambil data dari Register Kanker Finlandia, mendapatkan perbedaan survival yang bermakna antara tipe kanker tiroid tipe papiler, folikuler dan anaplastik. ${ }^{16}$ D.J. Kerr juga mendapatkan perbedaan survival yang sangat signifikan antara tipe papiler, folikuler, limfoma dan anaplastik. ${ }^{13}$

Jenis operasi yang paling banyak dilakukan adalah hemitiroidektomi yaitu sebanyak 74 (63,2\%) penderita, sedangkan tindakan total tiroidektomi adalah sebanyak $43(36,8 \%)$ penderita. Tingginya hemitiroidektomi dibandingkan dengan total tiroidektomi kemungkinan disebabkan banyaknya penderita yang menolak dilakukan completion thyroidectomy, yaitu operasi kedua untuk mengangkat 
jaringan kelenjar tiroid yang masih tersisa pasca tindakan ishtmolobektomi. Kemungkinan lain adalah karena banyaknya penderita yang tergolong Low risk menurut kriteria AMES pada penelitian ini yaitu sebanyak 88 (80\%) penderita dari 110 penderita kanker tiroid berdiferensiasi baik. Secara statistik tidak terdapat perbedaan survival yang bermakna antara operasi hemitiroid dengan total tiroidektomi $(p=0,618)$ (gb.6). Hasil ini sama seperti yang didapatkan oleh Harold Wanebo pada penelitian 347 penderita kanker tiroid yang diobati dari tahun 1975 sampai 1992 di Divisi Bedah Onkologi Bagian Bedah Universitas Brown, mendapatkan tidak ada perbedaan survival secara bermakna antara hemitiroid dengan total tiroidektomi. ${ }^{17}$ Demikian juga dengan L H Y Lim dalam penelitian pada 175 penderita kanker tiroid yang diobati di Bagian Bedah Rumah Sakit Umum Singapura dari tahun 1990 sampai 1997 juga tidak mendapatkan perbedaan survival yang bermakna antara hemitiroid dengan total tiroidektomi. ${ }^{(18)}$ lan $D$ Hay pada penelitian 320 penderita kanker tiroid yang dilakukan tiroidektomi selama kurun waktu 1940 sampai 2000 di Klinik Mayo juga tidak mendapatkan perbedaan survival yang bermakna antara total tiroidektomi dan hemitiroidektomi. ${ }^{19}$ Namun pada penelitian yang dilakukan oleh Brandon M. Barney yang menggunakan data base dari Surveillance, Epidemiology, and End Results (SEER) pada 23, 605 penderita kanker tiroid dari tahun 1983 sampai 2002 yang mendapatkan total tiroidektomi secara bermakna meningkatkan survival. ${ }^{11}$

Terapi adjuvan berupa supresi pada 21 orang penderita dan radioablasi 20 penderita. Tidak ada perbedaan survival bermakna antara yang mendapat terapi adjuvan dan yang tidak mendapat terapi adjuvan (nilai $p=0,506$ ) (gb.7). Hasil ini sama seperti yang didapatkan oleh Michael Coburn bahwa tidak terdapat perbedaan bermakna antara kanker tiroid yang mendapat terapi operasi saja dengan terapi operasi tambah ablasi. ${ }^{20}$ Hal yang sama didapatkan oleh lan D Hay juga tidak mendapatkan peningkatan survival pada penderita low risk yang mendapat radioablasi. ${ }^{19}$ Hasil berbeda didapatkan oleh Ernest $L$. Mazzaferri and Richard T. Kloos yang mendapatkan perbedaan survival yang bermakna antara penderita yang tidak mendapatkan ablasi dengan penderita yang mendapatkan ablasi. ${ }^{21}$ Demikian pula dengan hasil yang didapatkan oleh $\mathrm{R}$. Sciuto dan kawan-kawan, mendapatkan perbedaan survival yang bermakna antara yang mendapat radioablasi dengan yang tidak mendapat radioablasi. ${ }^{10}$

\section{KESIMPULAN}

1. Usia penderita kanker tiroid terbanyak didapatkan pada dekade ketiga.

2. Jenis kelamin terbanyak didapatkan pada perempuan, dengan perbandingan perempuan dan laki-laki adalah 7:1.

3. Faktor-faktor yang mempengaruhi ketahanan hidup kanker tiroid secara bermakna adalah umur, ukuran tumor, dan jenis histopatologi tumor.

4. Jenis kelamin, jenis operasi, dan dapat atau tidak dapat terapi adjuvan tidak mempengaruhi angka ketahanan hidup kanker tiroid secara bermakna pada penelitian ini.
5. Five survival rate kanker tiroid sangat baik, didapatkan overall five survival rate adalah $92,3 \%$.

\section{Daftar Pustaka}

1. McDougall IR. Thyroid Cancer: Epidemiology and Overview. In: Management of Thyroid Cancer and Related Nodular Disease. London: Springer. 2006; $p$ : 1-20.

2. Ramli M. Kanker Tiroid; Penatalaksanaan, Diagnosis, dan Terapi.In: Ramli M, Umbas R, Panigoro SS (editors). Deteksi Dini Kanker. Jakarta: Balai Penerbit FKUI. 2000; P: 9-31.

3. Mazzaferri EL, et al. An overview of the management of thyroid cancer. Practical Management of Thyroid Cancer : A Multidisciplinary Approach. Springer-Verlag London. 2006.

4. Suyatno, Pasaribu ET. Kanker Kelenjar Tiroid. In: Bedah Onkologi Diagnostik dan Terapi. Jakarta: Sagung Seto. 2010; p : 1-36.

5. Fige JJ. Epidemiology of Thyroid Cancer. In: Wartofsky L, Nostrand DV, editors. Thyroid Cancer ; A Comprehensive Guide to Clinical Management. New Jersey. 2006; p : 9-11.

6. Sampepajung D, Hamdani W. Thyroid Cancer : The Diagnose and The Management.

The Indonesian Journal of Medical Science. 2008; I (No. 2)

7. Dean DS, Hay ID. Prognostic Indicators in Differentiated Thyroid Carcinoma. Cancer Control. May/June 2000, Vol.7 (No.3): 229 39.

8. Cady B. Surgery of Thyroid Cancer. World Journal of Surgery. 1981; V: 3-14

9. Lestari DA. Frekuensi Multisentrisitas Kanker Tiroid Papiler Di RSUPN Cipto Mangunkusumo. Departemen IImu Bedah Fakultas Kedokteran Universitas Indonesia RSUPN Cipto Mangunkusumo 2010.

10. Sciuto R, et all. Natural history and clinical outcome of differentiated thyroid carcinoma: a retrospective analysis of 1503 patients treated at a single institution. Annals of Oncology 20. 2009; 1728-1735.

11. Barney BM, et al. Overall and Cause-spesific Survival for Patients Undergoing Lobectomy, Near-Total, or Total Thyroidektomy for Differentiated Thyroid Cancer. Head \& Neck. May 2011

12. Carcangiu ML, et al. Papillary Carcinoma of the Thyroid, A Clinicopathologic Study of 241 Cases Treated at the University of Florence Itali. Cancer. 1985; 55.

13. Kerr D.J, et al. Prognostik Faktor in Thyroid Tumor. British Journal Cancer. 1986; No. 54: 475-482.

14. Parikh HK, et al. Prognosticators of Survival In Differentitiated Thyroid Carcinoma. Indian Journal of Otolaryngology and Head and Neck Surgery. Vol. 52 No. 1, January- March 2001.

15. Ganly I et al. Management of Thyroid Cancer. In: Montgomery, editors. Principles and Practice of Head and Neck Surgery and Oncology. London. 2009. P: 413-443.

16. Franssila KO. Prognosis in Thyroid Carcinoma. Cancer. 1975; 36 : 1138-1146. 
17. Wanebo $\mathrm{H}$, et al. Total Tiroidectomy Does Not Enhance Disease Control or Survival Even in High-Risk Patiens With Differentiated Thyroid Cancer. Annals of Surgery. Vol. 227, No. 6. $1998: 912-921$

18. Lim LHY, et al. Well-diffierentiated Thyroid Carcinoma: Factors Predicting Recurrence and Survival. Singapore Med J. Vol 43(9). 2002 p: 457-462.

19. Hay ID, et al. Managing Patients With Papillary Thyroid Carcinoma: Insights Gained From The Mayo Clinic's Experience Of Treating 2,512 Consecutive Patients During 1940 Through 2000. Transactions Of The American Clinical And Climatological Association, Vol. 113, 2002.
20. Coburn M, et al. Recurrent Thyroid Cancer; Role of Surgery Versus Radioactive lodine $\left({ }^{131} \mathrm{I}\right)$. Annals of Surgery. 1994. Vol, 219; P: 587-595.

21. Mazzaferri EL, Kloos RT. Current Approaches to Primary Therapy for Papillary and Follicular Thyroid Cancer. The Journal of Clinical Endocrinology \& Metabolism. 2001; 86 (No. 4). 